\title{
An Integrative Review of School-Based Mental Health Interventions and Implications for Psychogenic Nonepileptic Seizures
}

Andrea Tanner, Wendy R Miller, Jane von Gaudecker, Janice M Buelow

\begin{abstract}
Millions of students with mental health concerns attend school each day. It is unknown how many of those students experience psychogenic non-epileptic seizures (PNES); however, quality of life, academic, and mental health outcomes for students experiencing PNES can be bleak. Currently, no authors have addressed potential school nurse interventions for students with PNES. Because PNES is a mental health condition and is often influenced by underlying anxiety and/or depression, an integrative review of school nurse interventions and outcomes for students with general mental health concerns was conducted. An integrative review resulted in the identification of 13 quantitative and 2 qualitative studies that met inclusion criteria. The findings from this review suggest school nurses, following principles from the Framework for $21^{\text {st }}$ Century School Nursing Practice, play an active role in mental health interventions and should be involved in replicating and testing known mental health interventions to investigate their effectiveness for students with PNES.
\end{abstract}

Keywords: school nurse interventions, mental health, psychogenic non-epileptic seizures, quality of life, academic outcomes, integrative review

This is the author's manuscript of the article published in final edited form as:

Tanner, A., Miller, W. R., Gaudecker, J. von, \& Buelow, J. M. (2020). An Integrative Review of School-Based Mental Health Interventions and Implications for Psychogenic Nonepileptic Seizures. The Journal of School Nursing, 36(1), 33-48. https://doi.org/10.1177/1059840519854796 
An Integrative Review of School-Based Mental Health Interventions and Implications for Psychogenic Non-Epileptic Seizures

Of the 56.6 million children and adolescents who attend school in the United States (National Center for Education Statistics, 2018), almost 3.5 million struggle with anxiety, depression, or a behavioral or conduct disorder (Centers for Disease Control and Prevention, 2018). A portion of these students have a condition called psychogenic non-epileptic seizures (PNES). PNES appear as epileptic seizures but show no abnormal brain activity on electroencephalogram (EEG) and have a psychological origin. The diagnosis is classified under the category of conversion/functional neurologic disorder within the Diagnostic and Statistical Manual of Mental Disorders Fifth Edition (DSM-V), a condition with nervous system symptoms in the absence of physical illness or injury often associated with stress (American Epilepsy Society, 2018; U. S. Department of Health \& Human Services, 2018). The extent of PNES in the school-aged population is unclear. Prevalence rates of 2-33/100,000 have been reported, with symptoms first starting, on average, at 13 years of age, but as early as age 5 (Asadi-Pooya \& Sperling, 2015; Yadav, Agarwal, \& Park, 2015). However, determining a prevalence rate for childhood PNES is difficult due to high misdiagnosis rates, few pediatric studies, and small study sample sizes (Smith, 2014).

The few studies conducted to better understand pediatric PNES reveal as many as 65$84 \%$ of students with PNES have unusually high levels of stress and anxiety while $44-55 \%$ have symptoms of depression (Plioplys et al., 2014; Sawchuk \& Buchhalter, 2015). Students with PNES experience higher rates of bullying, increased absenteeism, greater likelihood of learning problems, and decreased quality of life (QOL), especially in the domain of school functioning (Akdemir, Uzun, Pehlivantürk Özsungur, \& Topçu, 2013; Morgan \& Buchhalter, 2015; Plioplys 
et al., 2014). Children with PNES are also much more likely to express physical complaints, such a headaches, dizziness, weakness, and difficulty walking (Plioplys et al., 2014).

The school nurse may be the first to realize the extent of both psychological and psychosomatic complaints of students with PNES, as evidenced by frequent visits to the health office. Children and adolescents with PNES experience significant problems with relationships, school attendance, and academic performance (Morgan \& Buchhalter, 2015), which are issues school nurses may detect and address. Roughly $75 \%$ of schools in the United States employ a school nurse at least part-time to coordinate care for physical and mental health concerns (Willgerodt, Brock, \& Maughan, 2018). Yet, despite the school-centric nature of students' concerns and the presence of nurses in most schools to address their concerns, authors of pediatric PNES literature do not recognize school nurses as important contributors to the care of students with PNES (Caplan, Doss, Plioplys, \& Jones, 2017; Doss et al., 2017; Reilly, Menlove, Fenton, \& Das, 2013; Sawchuk \& Buchhalter, 2015). The American Epilepsy Society (2018) does acknowledge the role of the school nurse as first responder for PNES events and trainer of school personnel on how to respond to events; however, the only guidance for responding to PNES events at school includes encouraging bystanders to not interact with the student and to continue normal activities (American Epilepsy Society, 2018; Caplan et al., 2017). Despite documented mental health interventions_-including reassurance, clear communication regarding the diagnosis, parent education, and cognitive behavioral therapy (CBT)—being associated with reduction of PNES events (Caplan et al., 2017; Rawat et al., 2015; Sawchuk \& Buchhalter, 2015; Yadav, Agarwal, \& Park, 2015), the role of the school nurse beyond PNES event first responder is unclear.

A preliminary search of the literature revealed no school nurse intervention studies that 
address appropriate school nurse interventions for PNES; therefore, research is necessary to design and test school nurse interventions that may improve the QOL, academic, and mental health outcomes for students with PNES. Before school-based PNES interventions can be imagined and researched, it is important to examine school-based interventions for related conditions. Because PNES is a mental health condition and is often influenced by underlying anxiety and/or depression, one approach for planning PNES-specific interventions is to examine the state of the science of school nurse interventions for mental health concerns in general. Therefore, this integrative review answers the questions: "What school nurse interventions have been tested that address mental health concerns of students? What are the QOL, academic, and mental health outcomes of these interventions?"

\section{Methods}

This integrative review was completed using the methods outlined by Whittemore and Knafl (2005). This particular method is appropriate for the topic of PNES, school-based mental health, and school nurse interventions, because these concepts lack rigorous research and require reviewing both experimental and non-experimental literature to gain understanding. In accordance with Whittemore and Knafl's (2005) method, this integrative review included searching the literature, evaluating data, analyzing data, and presenting results.

\section{Search Strategy}

The literature search included utilizing CINAHL, MEDLINE, PsycINFO, and ERIC via EBSCO (see Figure). This combination of databases ensured the identification of nursing, school nursing, educational, and psychological literature. The search included the following search terms: "mental health" OR "anxiety" OR "depression" OR "stress" OR "conversion disorder" OR "somatic" AND "school nurse" OR "school health nurse" OR "school nursing" OR "school nurse 
intervention". To confirm a thorough search of school nursing literature, the author hand searched The Journal of School Nursing as well as reference lists of review articles regarding school nurse interventions.

\section{Search Criteria}

Articles were included in the integrative review if they addressed an actual or potential school nurse intervention for mental health concerns, focused on pediatric/child or adolescent age groups (capturing the ages of students in kindergarten through $12^{\text {th }}$ grade), and were written in English. Articles published in the last 20 years were included. Exclusion criteria included document types that fell under the categories of books, dissertations, reviews, editorial/opinion works, case studies, incomplete trial protocols, or informational pieces as well as works about substance abuse, identification/referral to other care providers, or school-based health centers where the nurse has prescriptive authority.

\section{Findings}

When limiting the search to English language and pediatric/child age, the search yielded 663 articles. After removing duplicates via EBSCO's "remove duplicates" command, 461 articles remained. A backward search of references from pertinent review articles revealed one additional article. A review of titles and abstracts for inclusion criteria (school nurse mental health interventions or potential interventions) whittled the remaining articles to 57 full-text documents. After applying the previously mentioned exclusion criteria, 15 full-text articles published between 1998 and 2017 met criteria for inclusion in the integrative review (see Figure).

\section{Evaluation of Data}

The Critical Appraisal Skills Programme (2018) checklist provided data evaluation 
criteria. Further discussion of empirical and theoretical traditions noted in the evaluation as well as their implications is included in a subsequent section. Details regarding each study's risk for bias were documented in Table 1. Due to the investigative nature of this review, meaningful information was gleaned from the studies' interventions and qualitative reports' themes. No articles were excluded due to quality of design or reporting.

\section{Data Extraction and Analysis}

Each article meeting inclusion and exclusion criteria was reviewed. Data related to the country in which each study was conducted, theoretical/framework underpinnings, study design, sample size and characteristics, intervention, measures, outcomes, risk of bias, and school nurse implications were extracted and summarized in Table 1 (characteristics of articles included in this review) and Table 2 (intervention and outcome details of quantitative studies). For quantitative studies, the details of school nurse interventions were further categorized into length of time required for intervention (number of sessions, frequency, and length of sessions), setting where intervention occurred, audience type (all students in a class, students targeted as "at risk" by a screening tool or process, or students already diagnosed with a condition), and type of school nurse interaction (one-on-one, small group, class, or family). To better understand what outcomes may be beneficial to measure in future school nurse intervention studies, intervention outcomes were categorized as QOL, academic, and mental health outcomes (see Table 2). These outcome categories reflect priorities of the National Association of School Nurses (NASN) and its Framework for $21^{\text {st }}$ Century School Nursing Practice (2016) by focusing on students and their QOL while also considering the academic impact of mental health concerns. The two qualitative studies were examined for themes related to school nurse interventions and outcomes and that offered a deeper understanding of the role school nurses play in student mental health care. 


\section{Study Characteristics}

The data extraction results (see Table 1) reveal important details about mental health interventions in schools. Of the 15 included studies, 9 were conducted in the United States (Fox, Rossetti, Burns, \& Popovich, 2005; Houck \& Stember, 2002; Hoying \& Melnyk, 2016; Kim et al., 2015; Lamb, Puskar, Sereika, \& Corcoran, 1998; Muggeo, Stewart, Drake, \& Ginsburg, 2017; Ramirez et al., 2013; Vessey \& O’neill, 2011; Wall, 2005) while the remaining studies were conducted in the United Kingdom (Spratt, Philip, Shucksmith, Kiger, \& Gair, 2010; Stallard, Simpson, Anderson, \& Goddard, 2008), Sweden (Clausson \& Berg, 2008; Johansson \& Ehnfors, 2006), Netherlands (Bannink et al., 2014), and Nigeria (Olowokere \& Okanlawon, 2014). The Journal of School Nursing published 5 of the 15 articles (Clausson \& Berg, 2008; Houck \& Stember, 2002; Hoying \& Melnyk, 2016; Olowokere \& Okanlawon, 2014; Vessey \& O’neill, 2011). Demonstrating the multidisciplinary nature of mental health, the remaining articles were published in journals covering topics such as internet research, psychiatric nursing, psychology/mental health, pediatric health care, and pastoral care in education.

Of the 15 studies, 6 included details about theories or frameworks that guided the study, the majority of which mentioned cognitive behavioral theory or similar mental health therapy as their basis (Clausson \& Berg, 2008; Fox et al., 2005; Hoying \& Melnyk, 2016; Lamb et al., 1998; Stallard et al., 2008; Wall, 2005). As is acceptable in an integrative review, the included studies varied in design type: randomized control trials (Bannink et al., 2014; Lamb et al., 1998), quasi-experimental (Fox et al., 2005; Houck \& Stember, 2002; Hoying \& Melnyk, 2016; Kim et al., 2015; Muggeo et al., 2017; Olowokere \& Okanlawon, 2014; Ramirez et al., 2013; Stallard et al., 2008), mixed methods (Clausson \& Berg, 2008; Vessey \& O’neill, 2011), feasibility (Wall, 2005), and qualitative (Johansson \& Ehnfors, 2006; Spratt et al., 2010). 


\section{Types of Interventions Tested}

This review includes a synthesis of findings based on a variety of school-based intervention studies. A report of qualitative studies follows in a subsequent section. In response to the first research question- "What school nurse interventions have been tested that address mental health concerns of students?"- the following results were obtained: web-based targeted messaging program (Bannink et al., 2014), therapeutic conversation with family (Clausson \& Berg, 2008), support group meetings (Houck \& Stember, 2002; Vessey \& O’neill, 2011), mental health courses embedded in general school curriculum (Hoying \& Melnyk, 2016), mental health engagement conversations during health office visits (Kim et al., 2015; Ramirez et al., 2013), coping skills training (Lamb et al., 1998), CBT sessions (Fox et al., 2005; Houck \& Stember, 2002; Muggeo et al., 2017; Stallard et al., 2008), resilience training (Olowokere \& Okanlawon, 2014; Vessey \& O’neill, 2011), and tai chi and mindfulness training (Wall, 2005). Although the interventions were similar in their attempt to offer psychoeducation and skills for coping with mental health concerns, they varied in their target audience type and size.

Targeted vs. universal. The 13 intervention studies included in the review involved one of two approaches: targeted toward an identified population or universal for all students. Authors of 9 of the 13 articles that examined interventions and their effectiveness described a targeted intervention approach, utilizing either assessment tools or input from school personnel to determine students at risk for or exhibiting mental health concerns (Bannink et al., 2014; Clausson \& Berg, 2008; Houck \& Stember, 2002; Kim et al., 2015; Lamb et al., 1998; Muggeo et al., 2017; Olowokere \& Okanlawon, 2014; Ramirez et al., 2013; Vessey \& O'neill, 2011). The other four intervention studies involved providing the intervention universally to all students, taking the stance that the skills taught during the interventions were helpful for all students, 
regardless of their risk for or current presentation of mental health concerns (Fox et al., 2005; Hoying \& Melnyk, 2016; Stallard et al., 2008; Wall, 2005). Three of the four universal programs were identified by authors as cognitive behavioral interventions or as having cognitive behavioral theoretical underpinnings (Fox et al., 2005; Hoying \& Melnyk, 2016; Stallard et al., 2008).

Group vs. individual. In addition to being categorized by intended audience, interventions were also categorized based on whether they were group or individual interventions. Of the thirteen intervention articles, four involved the school nurse intervening on an individual level. Three of the four individual-oriented interventions were structured as onetime therapeutic conversations (Bannink et al., 2014; Kim et al., 2015; Ramirez et al., 2013). The other was structured as repetitive interactions as a part of a CBT program (Muggeo et al., 2017).

The nine group interventions varied in group size. Intervention groups ranged from family units (Clausson \& Berg, 2008) to small groups (Fox et al., 2005; Houck \& Stember, 2002; Lamb et al., 1998; Olowokere \& Okanlawon, 2014; Stallard et al., 2008; Vessey \& O'neill, 2011; Wall, 2005) or entire school classes (Hoying \& Melnyk, 2016; Stallard et al., 2008). When larger groups were divided into smaller groups, the groups were divided based upon age (Fox et al., 2005; Lamb et al., 1998).

One-time interaction vs. multiple sessions. Interventions also varied in their use of onetime interaction or multiple sessions with students. Interventions consisting of a one-time conversation with the school nurse were noted in three articles (Bannink et al., 2014; Kim et al., 2015; Ramirez et al., 2013). The remaining ten articles consisted of interventions that involved multiple sessions, ranging in length from 3 sessions (Clausson \& Berg, 2008) to 15 sessions (Hoying \& Melnyk, 2016). Each session ranged in length from 30 minutes to 2 hours, although 
1-hour sessions were most commonly noted.

\section{Types of Outcomes Evaluated}

The studies in this literature review included an array of outcome measurements, which provided answers for the second research question: "What are the QOL, health, and academic outcomes of these interventions?" Of the 35 different outcome measures described in the intervention articles, only two measures were used in multiple studies - the Strengths and Difficulties Questionnaire (SDQ; Bannink et al., 2014; Clausson \& Berg, 2008) and Spence Children's Anxiety Scale (Olowokere \& Okanlawon, 2014; Stallard et al., 2008). Because of the extreme variability in outcome measures, between-study outcome comparisons could not be made.

Quality of life outcomes. Two research teams described student QOL as a motivation for their research (Bannink et al., 2014; Vessey \& O'neill, 2011), but only one research team reported the use of a QOL measure (Bannink et al., 2014). Bannink and colleagues (2014) chose the Child Health Questionnaire-Child Form (CHQ-CF-GH4) to measure student well-being (theoretically defined as mental health status and health-related QOL) in their one-time webbased, universal intervention. They found that student QOL scores improved slightly for students in general and moderately for students who were identified as high risk for mental health concerns (Bannink et al., 2014). While no other authors reported purposefully measuring QOL, other measures may have served as proxies for QOL.

Academic outcomes. When interventions take place in the school setting, researchers must be able to demonstrate academic benefits in order to gain school administration support. Of the 13 intervention articles, 4 included a measure related to students' academic confidence or abilities (Houck \& Stember, 2002; Hoying \& Melnyk, 2016; Muggeo et al., 2017; Stallard et al., 
2008). In a school-based weekly support group intervention for females at risk for depression and suicide, findings from a pre-/post-test comparison using High School Questionnaire (Houck $\&$ Stember, 2002) demonstrated a decrease in school drop-out risk. In a class-wide weekly physical activity and mental health intervention, researchers measured students' use of new skills from the program to improve academic performance, with $8.7 \%$ reporting using skills in this way (Hoying \& Melnyk, 2016).

When considering the effects of a small eight-week intervention study for students at risk for anxiety, the Behavior Assessment System for Children anxiety sub-scale measure was completed by teachers to measure problematic and adaptive school behaviors while the reading, writing, and math subtests of the Woodcock-Johnson Tests-Achievement and Cognitive Batteries were completed by students to measure memory and academic fluency (Muggeo et al., 2017). No statistically significant findings were noted for either measure. However, Muggeo and colleagues found school attendance improved between pre- and post-test measures of number of days missed in the last 2 weeks. Furthermore, teacher perception of concentration problems improved significantly from pre- to post-test as measured by the Teacher Observation of Classroom Adaptation-Checklist (Muggeo et al., 2017).

Academic Self-Esteem was measured as a part of the Culture Free Self-Esteem Questionnaire Form B used within a universal weekly CBT school mental health intervention (Stallard et al., 2008). Although Academic Self- Esteem scores increased each time the instrument was administered, the findings did not reach statistical significance.

Mental health outcomes. The majority of study outcomes examined the mental healthspecific outcomes with little discussion as to their impact on QOL or academic success. A list of instruments used can be found in Table 2 . The selected instruments measured a variety of mental 
health constructs reported as general mental health status (Bannink et al., 2014); psychological distress (Houck \& Stember, 2002); family strain (Houck \& Stember, 2002); depressive symptoms (Fox et al., 2005; Hoying \& Melnyk, 2016; Lamb et al., 1998; Olowokere \& Okanlawon, 2014; Ramirez et al., 2013); elevated anxiety symptoms (Hoying \& Melnyk, 2016; Muggeo et al., 2017; Olowokere \& Okanlawon, 2014; Stallard et al., 2008), disruptive behavior (Hoying \& Melnyk, 2016; Muggeo et al., 2017), anger (Hoying \& Melnyk, 2016); self-concept (Hoying \& Melnyk, 2016; Vessey \& O’neill, 2011); student readiness for mental health services (Kim et al., 2015); life events and coping styles during recent stressful life events (Lamb et al., 1998); somatic complaints (Muggeo et al., 2017); global functioning (Muggeo et al., 2017); selfesteem (Olowokere \& Okanlawon, 2014; Stallard et al., 2008); social connectedness (Olowokere \& Okanlawon, 2014); school connectedness (Ramirez et al., 2013); pediatric post-traumatic stress disorder (PTSD) symptoms (Ramirez et al., 2013); perceived social support from family, friends, and significant people (Ramirez et al., 2013); resilience (Olowokere \& Okanlawon, 2014; Vessey \& O’neill, 2011); and psychological functioning (Vessey \& O’neill, 2011).

Although many constructs were only examined in single studies, certain constructs stood out as common mental health indicators across several studies, including depressive symptoms (Fox et al., 2005; Hoying \& Melnyk, 2016; Lamb et al., 1998; Olowokere \& Okanlawon, 2014; Ramirez et al., 2013) and elevated anxiety symptoms (Hoying \& Melnyk, 2016; Muggeo et al., 2017; Olowokere \& Okanlawon, 2014; Stallard et al., 2008). Details about specific mental health outcomes are located in Table 2.

All studies demonstrated some level of mental health symptom improvement, regardless of type of audience (targeted vs. universal), type of meeting (group/class vs. individual), or length of intervention (one-time interaction vs. multiple sessions). For studies with universally 
delivered interventions, greater improvements were noted for students at risk of mental health concerns than students not at risk (Fox et al., 2005; Hoying \& Melnyk, 2016; Stallard et al., 2008; Wall, 2005). Only one of the individual-focused interventions involved multiple sessions, but post-intervention findings demonstrated mental health score improvements, similar to the group multi-session counterparts (Muggeo et al., 2017). One study (Bannink et al., 2014) involved a group web-based universal intervention prior to a targeted individual one-time intervention with a school nurse; those students who received the targeted school nurse intervention had improvements in more QOL and mental health measures than students who only participated in the web-based portion of the intervention. Again, those found at risk for mental health concerns experienced a slightly greater effect than the students not at risk. The other oneon-one, one-time interventions (Kim et al., 2015; Ramirez et al., 2013) targeted at-risk students only and noted improved mental health outcomes as well.

\section{Qualitative Study Findings}

The inclusion of two qualitative studies offered a more detailed glimpse into what makes school nurse interventions unique compared to other disciplines' interventions. In their qualitative study of school nurse managers, both Spratt and colleagues (2010) and Johansson and Ehnfors (2006) identified several key themes for school nurses' involvement with student mental health, including a distinctive opportunity to build trusting relationships through availability and students' ease of access to school nurses. Johansson and Ehnfors (2006) described using an introductory questionnaire that students completed before interacting with the school nurse to aid in therapeutic communication and relationship building. The questionnaire, designed to determine students' existing health and relationship problems, helped guide a more productive conversation between students and the school nurse. The authors of both qualitative studies 
provided insight into antecedents of therapeutic conversation including confidentiality, feeling safe to discuss mental health concerns (Spratt et al., 2010), trustworthiness, attentiveness, respectfulness, authenticity, and continuity of seeing the same nurse over several visits or over several years (Johansson \& Ehnfors, 2006).

\section{Discussion}

\section{Theoretical Traditions}

With fewer than half of the reviewed studies including reports of theoretical underpinnings, there is much room for researchers to advance school nursing knowledge based on the foundation of theory. Beck's (1976) cognitive therapy model-based CBT intervention was the most tested intervention in school nursing mental health intervention studies and has also been the primary intervention tested in PNES psychological research (Cope, Poole, \& Agrawal, 2017; Sawchuk \& Buchhalter, 2015; Takasaki, Diaz, \& Ma, 2016). CBT is a theory-based, scientifically supported psychological treatment for depression, anxiety disorders, severe mental illness, and PNES (American Psychological Association, 2018; Smith, 2014). The therapy is established on the principal that mental health concerns are based, to a certain extent, on faulty or unhelpful thinking and learned patterns of unhelpful behaviors (American Psychological Association, 2018). CBT is valued for its attention to skills that can benefit all students, not just those with identified mental health concerns (Hoying \& Melnyk, 2016). Because CBT can provide skills beneficial to all students, it is a promising strategy for addressing some of the mental health care needs of students with PNES and many other identified or undiagnosed mental health concerns. Conversely, universal school-based interventions do not replace the individualized and specialized care of a mental health care professional.

School nurses may find CBT-based interventions attractive because of their flexibility 
and short duration. Interestingly, of the four studies that reported interventions delivered at the individual level, three were one-time interventions rather than extended multi-session interventions (Bannink et al., 2014; Kim et al., 2015; Ramirez et al., 2013). This observation is pertinent to the common concern of school nurses regarding the time consuming nature of mental health care and the lack of time and resources to provide such care (Johansson \& Ehnfors, 2006). Researchers demonstrated that even one brief conversation can make a difference (albeit statistically small) in the life of a student with a mental health concern, as can longer, more structured interventions.

\section{Empirical Traditions}

Researchers conducting school-based intervention studies encounter a variety of challenges. Researchers most often used a quasi-experimental research design, using pre-/posttest measures without comparison or control groups because of their desire to provide a beneficial opportunity to as many students as possible. Attrition and inability to control for the effect of seasonal changes on affect and mood scores were challenges for research conducted over several months within the same school year. The qualitative studies lacked rigor by failing to provide clear statements of methodology, design, and analysis appropriate for the studies' aims. Because there is little risk of harm in implementing the tested mental health interventions, less rigorous quasi-experimental and qualitative studies can inform future PNES research and interventions with caution. On the other hand, increased use of randomized control trials could provide greater support for seeking additional funding, creating research opportunities that build upon existing research, and making generalizations for school nursing practice.

Although novel and evidence-based interventions were tested, the vast array of measured outcomes precluded any comparison of outcome findings between studies. Only one research 
team included QOL as an explicit outcome. Also lacking in studies were academic outcome measures. If researchers want to seek not only permission but also collaboration with schools and education teams, a greater focus must be placed on outcome measures that interest schools, especially school attendance (Attendance Works, 2018), school performance, and learning difficulties among students with PNES and other mental health concerns (Doss et al., 2017).

\section{From Mental Health Interventions to PNES Interventions}

Although researchers have advanced knowledge of school-based mental health intervention effectiveness, there are no empirical data to support feasibility and acceptability of current recommendations for responding to PNES events. The American Epilepsy Society (2018), Epilepsy Foundation (2018), and Caplan and colleauges (2017) provided recommendations regarding how school personnel should respond when a student experiences a PNES event. Suggested steps include 1) avoiding emergency medical care unless an injury occurs or seizure activity is unlike previous events, 2) continuing with class without drawing attention to or talking to the student during the event, and 3) encouraging the student to return to class or normal activities as soon as possible after the event. Little is known about schools' knowledge or use of the above PNES guidance or the experience of school personnel, classmates, and students with PNES when the recommendations are followed.

\section{Summary of Findings}

This integrative review offers an analysis of 13 intervention studies, as well as 2 qualitative studies, in which authors investigated a variety of school-based mental health interventions. Most interventions were initiated and/or conducted by school nurses and went beyond simply identifying and referring students to mental health care services. The general mental health interventions could be implemented for students with PNES individually or with 
other students with and without mental health concerns to investigate their effectiveness on QOL, academic, and mental health outcomes.

Although research exists that tests interventions for the underlying mental health needs of students with PNES, school nurses need evidence-based guidance for PNES-specific interventions, including how to handle the seizure events as they happen. Guidance found in epilepsy organization reports and textbooks provide untested recommendations for handling PNES events in school. The NASN released evidence-based clinical guidelines for the care of students with seizures and epilepsy (Lepkowski \& Maughan, 2018); however, the project-lead confirmed that the guidelines are only intended for those with abnormal electrical brain activity, not for those experiencing PNES (A. Lepkowski, personal communication, October 17, 2018). This review highlights tested school nurse interventions and the QOL, health, and academic measures used to evaluate their effectiveness.

\section{Future Directions and Conclusion}

Future research should consider the NASN (2016) Framework's principles while applying lessons learned from mental health interventions to newly designed PNES interventions. Guided by such works as Best, Oppewal, and Travers' (2018) review of school nurse interventions and outcomes, PNES interventions should target both the underlying mental health aspects of PNES as well as the immediate needs of students before, during, and after PNES events. School nurses, in collaboration with a multidisciplinary team of experts, should consider how the NASN's Seizure Guideline (Lepkowski \& Maughan, 2018) can inform PNESspecific guidelines. The feasibility of one-time, individual student interventions and the supportive evidence of universal CBT provide two different approaches that may fuel future PNES research. Additionally, suggested guidelines for responding to PNES events at school 
should be tested for appropriateness in the school setting. Outcomes should be chosen based on QOL, academic, and mental health considerations and be consistently defined and measured.

School nurse research must be increased in rigor and replicability to gain resources and financial support for future intervention programs. The national shortage of mental health care providers (Health Resources and Services Administration, 2018) and the lack of providers trained in PNES care in many regions, increase the need for school nurses to help meet mental health care needs of students with PNES. School nurses provide direct care, follow-up, home visits, and mental health support with no added cost to the health care system or society. By incorporating the school nurse into mental health interventions, students can receive care while overcoming socio-economic barriers such as lack of transportation, parents' work schedule, and poor parent follow-through. With a better understanding of both educational and health needs of students with PNES, $21^{\text {st }}$ century school nurses are poised and ready to better meet the needs of students with PNES and other mental health concerns. 


\section{References}

Akdemir, D., Uzun, Ö., Pehlivantürk Özsungur, B., \& Topçu, M. (2013). Health-related quality of life in adolescents with psychogenic nonepileptic seizures. Epilepsy \& Behavior, 29(3), 516-520. https://doi.org/10.1016/j.yebeh.2013.09.015

American Epilepsy Society. (2018). Psychogenic non-epileptic seizures (PNES) for mental health professionals. Retrieved from https://www.aesnet.org/sites/default/files/file_attach/5 PNESInfoSheet_MentalHealthPros_FINAL 7-17-2018.pdf

American Psychological Association. (2018). What is cognitive behavioral therapy? Retrieved November 30, 2018, from https://www.apa.org/ptsd-guideline/patients-andfamilies/cognitive-behavioral.aspx

Asadi-Pooya, A. A., \& Sperling, M. R. (2015). Epidemiology of psychogenic nonepileptic seizures. Epilepsy \& Behavior, 46, 60-65. https://doi.org/10.1016/j.yebeh.2015.03.015

Attendance Works. (2018). Key research: Why attendance matters for achievement and how interventions can help key research. Retrieved from https://awareness.attendanceworks.org/wp-content/uploads/Research2016.pdf

Bannink, R., Broeren, S., Joosten-Van Zwanenburg, E., Van As, E., Van De Looij-Jansen, P., \& Raat, H. (2014). Effectiveness of a web-based tailored intervention (E-health4Uth) and consultation to promote adolescents' health: Randomized controlled trial. Journal of Medical Internet Research, 16(5). https://doi.org/10.2196/jmir.3163

Beck, A. T. (1976). Cognitive therapy and the emotional disorders. New York, NY: International Universities Press.

Best, N. C., Oppewal, S., \& Travers, D. (2018). Literature review exploring school nurse interventions and health and education outcomes: An integrative review. Journal of School 
Nursing, 34(1), 14-27. https://doi.org/10.1177/1059840517745359

Caplan, R., Doss, J., Plioplys, S., \& Jones, J. (2017). Pediatric psychogenic non-epileptic seizures: A treatment guide. New York, NY: Springer.

Centers for Disease Control and Prevention. (2018). Data \& statistics. Retrieved from https://www.cdc.gov/childrensmentalhealth/data.html

Clausson, E., \& Berg, A. (2008). Family intervention sessions: One useful way to improve schoolchildren's mental health. Journal of Family Nursing, 14(3), 289-313.

Cope, S. R., Poole, N., \& Agrawal, N. (2017). Treating functional non-epileptic attacks - Should we consider acceptance and commitment therapy? Epilepsy and Behavior, 73, 197-203. https://doi.org/10.1016/j.yebeh.2017.06.003

Critical Appraisal Skills Programme. (2018). CASP-Randomised-Controlled-Trial-Checklist2018. Retrieved from www.casp-uk.net

Doss, J., Caplan, R., Siddarth, P., Bursch, B., Falcone, T., Forgey, M., ... Plioplys, S. (2017). Risk factors for learning problems in youth with psychogenic non-epileptic seizures. Epilepsy \& Behavior, 70, 135-139. https://doi.org/10.1016/j.yebeh.2017.03.016

Epilepy Foundation. (2018). Caring for students diagnosed with psychogenic non-epileptic seizures (PNES) [PowerPoint Slides]. Louisville, KY.

Fox, P., Rossetti, J., Burns, K., \& Popovich, J. (2005). Southeast Asian refugee children: A school-based mental health intervention. International Journal of Psychiatric Nursing Research, 11(1), 1227-1236. Retrieved from http://search.ebscohost.com/login.aspx?direct=true\&db=rzh\&AN=106542898\&site=ehostlive

Health Resources and Services Administration. (2018). Designated health professional shortage 
areas statistics. Retrieved from

https://data.hrsa.gov/Default/GenerateHPSAQuarterlyReport

Houck, G. M., \& Stember, L. (2002). A support group intervention for at-risk female high school students. Journal of School Nursing, 18(4), 212-218.

Hoying, J., \& Melnyk, B. M. (2016). COPE: A pilot study with urban-dwelling minority sixthgrade youth to improve physical activity and mental health outcomes. Journal of School Nursing, 32(5), 347-356. https://doi.org/10.1177/1059840516635713

Johansson, A., \& Ehnfors, M. (2006). Mental health-promoting dialogue of school nurses from the perspective of adolescent pupils. Nursing Science, 26(4), 10-13, 19.

Kim, R., Becker, K., Stephan, S., Hakimian, S., Apocada, D., Escudero, P., \& Chorpita, B. (2015). Connecting students to mental health care: Pilot findings from an engagement program for school nurses. Advances in School Mental Health Promotion, 8(2), 878-103. https://doi.org/doi:10.1080/1754730X.2015.1021821

Lamb, J. M., Puskar, K. R., Sereika, S. M., \& Corcoran, M. (1998). School-based intervention to promote coping in rural teens. MCN. The American Journal of Maternal Child Nursing, 23(4 CC-Child Health CC-Common Mental Disorders CC-SR-HEALTHP), 187-194. Retrieved from https://www.cochranelibrary.com/central/doi/10.1002/central/CN00152607/full

Lepkowski, A., \& Maughan, E. (2018). School nursing evidence-based practice clinical guideline: Students with seizures and epilepsy. Silver Spring, MD. Retrieved from https://cdn.fs.pathlms.com/GngsroHbTKyiLsB60wfl?cache=true

Morgan, L. A., \& Buchhalter, J. (2015). Psychogenic paroxysmal nonepileptic events in children: A review. Pediatric Neurology, 53(1), 13-22. 
https://doi.org/10.1016/j.pediatrneurol.2015.03.017

Muggeo, M. A., Stewart, C. E., Drake, K. L., \& Ginsburg, G. S. (2017). A school nursedelivered intervention for anxious children: An open trial. School Mental Health, 9(2), 157171. https://doi.org/10.1007/s12310-017-9211-X

National Association of School Nurses. (2016). Framework for 21st Century School Nursing Practice. Retrieved from https://www.nasn.org/nasn/nasn-resources/professionaltopics/framework

National Center for Education Statistics. (2018). Fast facts. Retrieved from https://nces.ed.gov/fastfacts/

Olowokere, A. E., \& Okanlawon, F. A. (2014). The effects of a school-based psychosocial intervention on resilience and health outcomes among vulnerable children. Journal of School Nursing, 30(3), 206-215. https://doi.org/10.1177/1059840513501557

Plioplys, S., Doss, J., Siddarth, P., Bursch, B., Falcone, T., Forgey, M., ... Caplan, R. (2014). A multisite controlled study of risk factors in pediatric psychogenic nonepileptic seizures. Epilepsia, 55(11), 1739-1747. https://doi.org/10.1111/epi.12773

Ramirez, M., Harland, K., Frederick, M., Shepherd, R., Wong, M., \& Cavanaugh, J. E. (2013). Listen protect connect for traumatized schoolchildren: A pilot study of psychological first aid. BMC Psychology, 1(1), 1-9. https://doi.org/10.1186/2050-7283-1-26

Rawat, V. S., Dhiman, V., Sinha, S., John Vijay Sagar, K., Thippeswamy, H., Kumar Chaturvedi, S., ... Satishchandra, P. (2015). Co-morbidities and outcome of childhood psychogenic non-epileptic seizures-An observational study. Seizure, 25, 95-98. https://doi.org/10.1016/j.seizure.2014.09.011

Reilly, C., Menlove, L., Fenton, V., \& Das, K. B. (2013). Psychogenic nonepileptic seizures in 
children: A review. Epilepsia, 54(10), 1715-1724. https://doi.org/10.1111/epi.12336

Sawchuk, T., \& Buchhalter, J. (2015). Psychogenic nonepileptic seizures in children —

Psychological presentation, treatment, and short-term outcomes. Epilepsy \& Behavior, 52, 49-56. https://doi.org/10.1016/j.yebeh.2015.08.032

Smith, B. J. (2014). Closing the major gap in PNES research: Finding a home for a borderland disorder. Epilepsy Currents, 14(2), 63-67. https://doi.org/10.5698/1535-7597-14.2.63

Spratt, J., Philip, K., Shucksmith, J., Kiger, A., \& Gair, D. (2010). “We are the ones that talk about difficult subjects": Nurses in schools working to support young people's mental health. Pastoral Care in Education, 28(2), 131-144.

https://doi.org/10.1080/02643944.2010.482145

Stallard, P., Simpson, N., Anderson, S., \& Goddard, M. (2008). The FRIENDS emotional health prevention programme: 12 month follow-up of a universal UK school based trial. European Child and Adolescent Psychiatry, 17(5), 283-289. https://doi.org/10.1007/s00787-007$0665-5$

Takasaki, K., Diaz, A., \& Ma, G. M. (2016). Psychogenic nonepileptic seizures: Diagnosis, management, and bioethics. Pediatric Neurology, 62, 3-8. https://doi.org/10.1016/j.pediatrneurol.2016.04.011

U. S. Department of Health \& Human Services. (2018). Conversion disorder. Retrieved from https://rarediseases.info.nih.gov/diseases/6191/conversion-disorder

Vessey, J. A., \& O’neill, K. M. (2011). Helping students with disabilities better address teasing and bullying situations: A MASNRN study. Journal of School Nursing, 27(2), 139-148. https://doi.org/10.1177/1059840510386490

Wall, R. B. (2005). Tai Chi and mindfulness-based stress reduction in a Boston public middle 
school. Journal of Pediatric Health Care, 19(4), 230-237.

https://doi.org/10.1016/j.pedhc.2005.02.006

Whittemore, R., \& Knafl, K. (2005). The integrative review: Updated methodology. Journal of Advanced Nursing, 52(5), 546-553. https://doi.org/10.1111/j.1365-2648.2005.03621.x

Willgerodt, M. A., Brock, D. M., \& Maughan, E. D. (2018). Public School Nursing Practice in the United States. Journal of School Nursing, 34(3), 232-244.

https://doi.org/10.1177/1059840517752456

Yadav, A., Agarwal, R., \& Park, J. (2015). Outcome of psychogenic nonepileptic seizures ( PNES ) in children : A 2-year follow-up study. Epilepsy \& Behavior, 53, 168-173.

Yadav, A., Agarwal, R., \& Park, J. (2015). Outcome of psychogenic nonepileptic seizures (PNES) in children: A 2-year follow-up study. Epilepsy \& Behavior, 53, 168-173. doi: https://doi.org/10.1016/j.yebeh.2015.10.017 
Figure

PRISMA Flowchart Reporting the Literature Selection Process
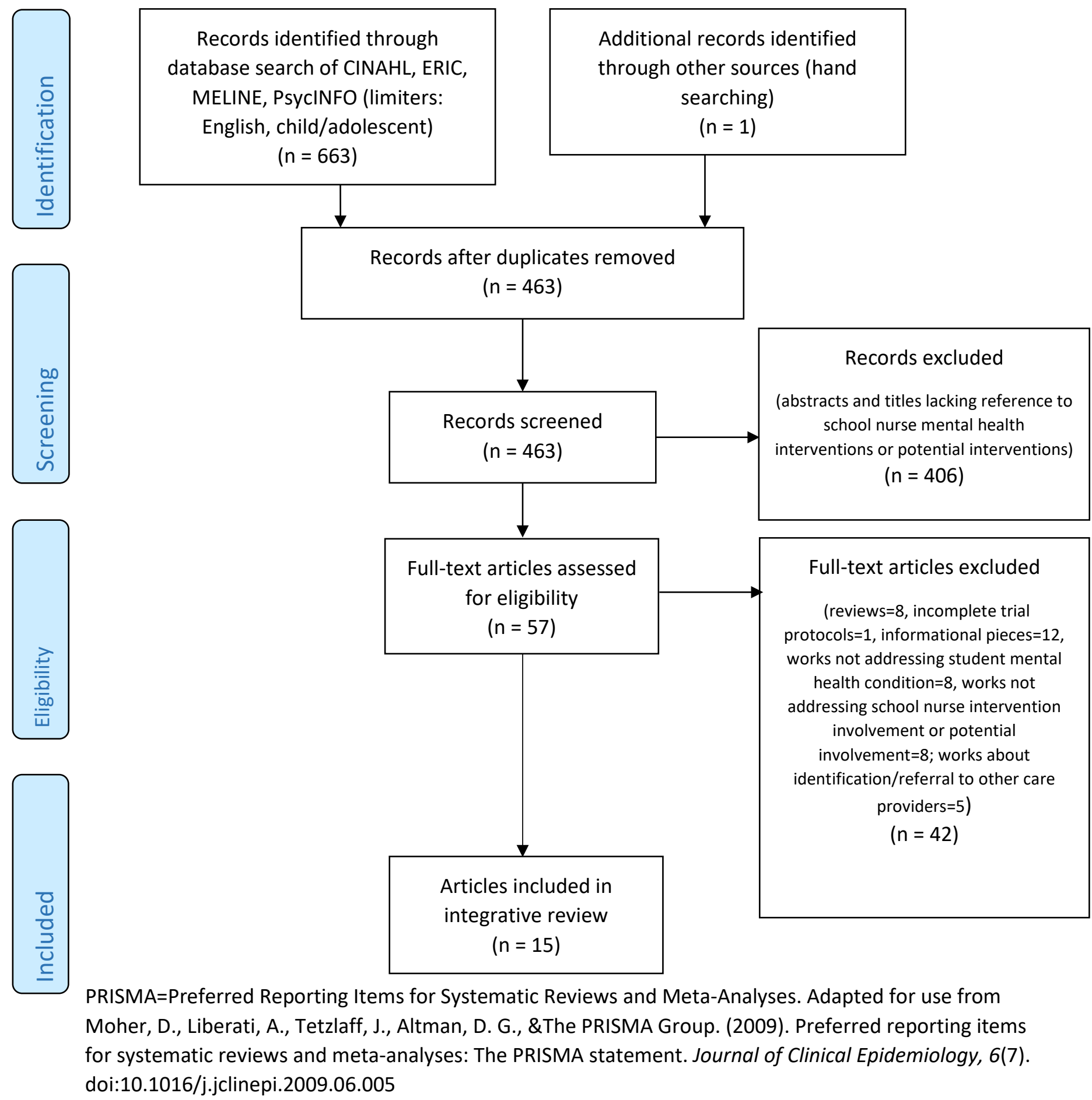
Table 1

\section{Article Characteristics}

\begin{tabular}{|c|c|c|c|c|c|}
\hline $\begin{array}{l}\text { First } \\
\text { Author, } \\
\text { Year }\end{array}$ & Theory & $\begin{array}{l}\text { Country } \\
\text { Design } \\
\text { Sample }\end{array}$ & Intervention Summary & Risk of Bias & Implications \\
\hline $\begin{array}{l}\text { Bannink, } \\
2014 \\
\text { Journal of } \\
\text { Medical } \\
\text { Internet } \\
\text { Research }\end{array}$ & Not reported & $\begin{array}{l}\text { Netherlands } \\
\text { 3-armed cluster } \\
\text { RCT } \\
1256 \\
\text { adolescents }\end{array}$ & $\begin{array}{l}\text { E-health4U tailored web-based mental } \\
\text { health wellbeing messages with and } \\
\text { without school nurse consultation } \\
\text { using motivational interviewing for } \\
\text { adolescents at risk for mental health } \\
\text { concerns (according to web-based } \\
\text { program) }\end{array}$ & $\begin{array}{l}\text { Risk lowered due to large } \\
\text { sample size and RCT } \\
\text { design, although use of } \\
\text { self-report and attrition rate } \\
\text { of non-Dutch lower } \\
\text { educated adolescents } \\
\text { could make results less } \\
\text { generalizable }\end{array}$ & $\begin{array}{l}\text { Future study should examine } \\
\text { school nurse consultation } \\
\text { alone without web-based } \\
\text { program. School nurse portion } \\
\text { of intervention made greatest } \\
\text { impact; however, web-based } \\
\text { program can inform school } \\
\text { nurse of student needs. }\end{array}$ \\
\hline $\begin{array}{l}\text { Clausson, } \\
2008 \\
\text { Journal of } \\
\text { School } \\
\text { Nursing }\end{array}$ & $\begin{array}{l}\text { Illness Beliefs } \\
\text { Model, Calgary } \\
\text { Family } \\
\text { Assessment } \\
\text { and } \\
\text { Intervention } \\
\text { Models }\end{array}$ & $\begin{array}{l}\text { Sweden } \\
\text { Mixed methods } \\
\text { (qualitative with } \\
\text { pre-test/post- } \\
\text { test) } \\
4 \text { school } \\
\text { children, their } \\
\text { families and } \\
\text { school nurses }\end{array}$ & $\begin{array}{l}\text { Therapeutic conversations with } \\
\text { families (through family sessions) in } \\
\text { alleviating recurring health complaints } \\
\text { among adolescent girls in a school } \\
\text { setting. Two school nurses used a } \\
\text { semi-structured guide written by the } \\
\text { authors. Also, developing ecomaps } \\
\text { and genograms with the family and } \\
\text { sending therapeutic letter from school } \\
\text { nurse to family were used as } \\
\text { interventions. }\end{array}$ & $\begin{array}{l}\text { Overgeneralization of } \\
\text { positive results with no } \\
\text { statistical reporting in write- } \\
\text { up }\end{array}$ & $\begin{array}{l}\text { School nurse family sessions } \\
\text { using ecomaps and } \\
\text { genograms and closing } \\
\text { affirming letter may improve } \\
\text { student and family perceptions } \\
\text { of impact of managing mental } \\
\text { health and somatic symptoms. }\end{array}$ \\
\hline $\begin{array}{l}\text { Fox, } 2005 \\
\text { Internation- } \\
\text { al Journal } \\
\text { of } \\
\text { Psychiatric } \\
\text { Nursing } \\
\text { Research }\end{array}$ & $\begin{array}{l}\text { Cognitive } \\
\text { behavioral }\end{array}$ & $\begin{array}{l}\text { US } \\
\text { pre-test, post- } \\
\text { test } \\
58 \text { Southeast } \\
\text { Asia refugee } \\
\text { children aged 6- } \\
15\end{array}$ & $\begin{array}{l}\text { School based cognitive-behavioral } \\
\text { program provided by } \\
\text { bilingual/bicultural teachers, school } \\
\text { nurses, and nurse researchers }\end{array}$ & $\begin{array}{l}\text { Small sample size, no } \\
\text { comparison group, } \\
\text { including all SEA children } \\
\text { instead of only those with } \\
\text { depressive symptoms may } \\
\text { have masked greater } \\
\text { effect. It is possible that } \\
\text { similar scores would have } \\
\text { been found in non-SEA } \\
\text { students living in similar } \\
\text { sociodemographic } \\
\text { situation. }\end{array}$ & $\begin{array}{l}\text { Utilizing schools can be an } \\
\text { effective way to mitigate effects } \\
\text { of poverty in a cost-effective } \\
\text { way. }\end{array}$ \\
\hline
\end{tabular}




\begin{tabular}{|c|c|c|c|c|c|}
\hline $\begin{array}{l}\text { First } \\
\text { Author, } \\
\text { Year }\end{array}$ & Theory & $\begin{array}{l}\text { Country } \\
\text { Design } \\
\text { Sample }\end{array}$ & Intervention Summary & Risk of Bias & Implications \\
\hline $\begin{array}{l}\text { Houck, } \\
2002 \\
\text { Journal of } \\
\text { School } \\
\text { Nursing }\end{array}$ & Not reported & $\begin{array}{l}\text { US } \\
\text { pre-test, post- } \\
\text { test } \\
14 \text { female } \\
\text { students } \\
\text { identified by } \\
\text { school nurse or } \\
\text { school } \\
\text { counselor as } \\
\text { exhibiting } \\
\text { depressive s/s }\end{array}$ & $\begin{array}{l}\text { Sessions co-led by school nurse and a } \\
\text { mental health counselor with cognitive- } \\
\text { behavioral and psychoeducational } \\
\text { focus. School nurse selected program } \\
\text { to meet his/her preferences. }\end{array}$ & $\begin{array}{l}\text { Poor description of data } \\
\text { collection. Need to plan for } \\
\text { latency in effect. School } \\
\text { nurses choose the } \\
\text { program they wished to } \\
\text { use, so no consistency in } \\
\text { intervention for } \\
\text { comparison. No } \\
\text { comparison group. }\end{array}$ & $\begin{array}{l}\text { School nurses were well } \\
\text { positioned to offer an } \\
\text { intervention with outcomes of } \\
\text { complete elimination of suicidal } \\
\text { thoughts and drug use as well } \\
\text { as improved school bonding } \\
\text { and increased likelihood of } \\
\text { students connecting with } \\
\text { mental health care resources. }\end{array}$ \\
\hline $\begin{array}{l}\text { Hoying, } \\
2016 \\
\text { Journal of } \\
\text { School } \\
\text { Nursing }\end{array}$ & $\begin{array}{l}\text { Cognitive- } \\
\text { behavioral skill } \\
\text { building/CBT }\end{array}$ & $\begin{array}{l}\text { US } \\
\text { one group pre- } \\
\text { and posttest } \\
\text { experimental } \\
\text { design, } \\
\text { feasibility pilot } \\
\text { study } \\
316 \text { th grade } \\
\text { convenience } \\
\text { sample age 11- } \\
13\end{array}$ & $\begin{array}{l}\text { Manualized CBSB program based on } \\
\text { CBT principles utilizing } 12 \text { empirically } \\
\text { based concepts }\end{array}$ & $\begin{array}{l}\text { One-group study design, } \\
\text { no control group, no } \\
\text { measurement of long-term } \\
\text { effects. Confounding } \\
\text { factors such as change in } \\
\text { season could impact } \\
\text { results. }\end{array}$ & $\begin{array}{l}\text { Correlation findings support } \\
\text { school nurses using the CBSB } \\
\text { techniques found in COPE to } \\
\text { improve preteens' self-concept, } \\
\text { healthy lifestyle beliefs, and } \\
\text { possibly physical activity. }\end{array}$ \\
\hline $\begin{array}{l}\text { Johansson, } \\
2006 \\
\text { Nursing } \\
\text { Science }\end{array}$ & Not reported & $\begin{array}{l}\text { Sweden } \\
\text { Descriptive } \\
\text { design using } \\
\text { inductive } \\
\text { qualitative } \\
\text { content analysis }\end{array}$ & $\begin{array}{l}\text { Mental health-promoting dialogue with } \\
\text { the school nurse }\end{array}$ & $\begin{array}{l}\text { Thorough description of } \\
\text { analysis provided } \\
\text { decreased risk of bias. } \\
\text { Authors may be } \\
\text { overemphasizing the role } \\
\text { of "good dialogue" in } \\
\text { mental health without } \\
\text { supporting the statement } \\
\text { with empirical data. Using } \\
\text { focus groups may limit }\end{array}$ & $\begin{array}{l}\text { Every dialogue is an } \\
\text { opportunity for school nurses } \\
\text { to promote mental health. } \\
\text { Students see value in knowing } \\
\text { and being able to talk with their } \\
\text { school nurse. Dialogues with } \\
\text { the school nurse can serve in } \\
\text { primary, secondary, and } \\
\text { tertiary prevention roles. }\end{array}$ \\
\hline
\end{tabular}




\begin{tabular}{|c|c|c|c|c|c|}
\hline $\begin{array}{l}\text { First } \\
\text { Author, } \\
\text { Year }\end{array}$ & Theory & $\begin{array}{l}\text { Country } \\
\text { Design } \\
\text { Sample }\end{array}$ & Intervention Summary & Risk of Bias & Implications \\
\hline & & $\begin{array}{l}26 \text { 15-year-olds } \\
\text { placed into } 5 \\
\text { focus groups }\end{array}$ & & $\begin{array}{l}\text { openness in discussing } \\
\text { sensitive topics. }\end{array}$ & \\
\hline $\begin{array}{l}\text { Kim, } 2015 \\
\text { Advances } \\
\text { in School } \\
\text { Mental } \\
\text { Health } \\
\text { Promotion }\end{array}$ & Not reported & $\begin{array}{l}\text { US } \\
\text { pilot feasibility } \\
\text { study, pre-test } \\
\text { post-test } \\
6 \text { school nurses } \\
\text { and } 25 \\
\text { adolescents }\end{array}$ & $\begin{array}{l}\text { School nurses trained to deliver } \\
\text { psychoeducation about the problem } \\
\text { and services, assessment of barriers } \\
\text { to services, problem solving those } \\
\text { barriers, setting positive expectations } \\
\text { for services, eliciting change talk to } \\
\text { address problem, planning for referral, } \\
\text { and following up with the student }\end{array}$ & $\begin{array}{l}\text { Actual follow through for } \\
\text { adolescents seeking } \\
\text { mental health services not } \\
\text { measured, but youth } \\
\text { readiness for services was. }\end{array}$ & $\begin{array}{l}\text { Further testing needed. Need } \\
\text { for longer training time. } \\
\text { Program seems to be feasible } \\
\text { and accepted by school } \\
\text { nurses. }\end{array}$ \\
\hline $\begin{array}{l}\text { Lamb, } \\
1998 \\
\text { American } \\
\text { Journal of } \\
\text { Maternal } \\
\text { Child } \\
\text { Nursing }\end{array}$ & $\begin{array}{l}\text { Developmental } \\
\text { tasks of } \\
\text { adolescence, } \\
\text { didactic and } \\
\text { cognitive- } \\
\text { behavioral } \\
\text { group models, } \\
\text { and coping }\end{array}$ & $\begin{array}{l}\text { US } \\
\text { Two-phase } \\
\text { experimental } \\
\text { study } \\
222 \text { rural high } \\
\text { school students } \\
\text { surveyed, } 41 \\
\text { with depressive } \\
\text { symptoms } \\
\text { and/or suicidal } \\
\text { ideation and } \\
\text { were } \\
\text { randomized into } \\
\text { control and } \\
\text { intervention } \\
\text { groups }\end{array}$ & $\begin{array}{l}\text { Cognitive-behavioral model with a } \\
\text { standard protocol, didactic content on } \\
\text { common teen stresses, self- image, } \\
\text { coping, family relationships, and } \\
\text { communication, experiential learning } \\
\text { through identifying their problems and } \\
\text { engaging in concrete problem solving } \\
\text { tasks, group discussion, role-play, } \\
\text { problem solving, worksheets, } \\
\text { handouts, films, audio tapes, and } \\
\text { group projects, and homework. }\end{array}$ & $\begin{array}{l}\text { Timing of pretest in winter } \\
\text { and posttest in late spring } \\
\text { could confound depressive } \\
\text { symptom results. Females } \\
\text { were more responsive to } \\
\text { intervention than males; } \\
\text { future study should use } \\
\text { male interventionists, } \\
\text { especially for male groups } \\
\text { to see if gender affects } \\
\text { outcomes. Further testing } \\
\text { should be done to } \\
\text { determine effectiveness in } \\
\text { non-rural settings. }\end{array}$ & $\begin{array}{l}\text { Intervention was feasible for } \\
\text { school nurses and could be } \\
\text { very beneficial for rural } \\
\text { adolescents who may not have } \\
\text { access to mental health } \\
\text { services. }\end{array}$ \\
\hline $\begin{array}{l}\text { Muggeo, } \\
2017 \\
\text { School } \\
\text { Mental } \\
\text { Health }\end{array}$ & Not reported & $\begin{array}{l}\text { US } \\
\text { Pre-/post-test } \\
\text { feasibility study }\end{array}$ & $\begin{array}{l}\text { Nurse-administered intervention } \\
\text { (CALM-Child Anxiety Learning } \\
\text { Modules) based on cognitive } \\
\text { behavioral strategies to reduce anxiety } \\
\text { symptoms and improve academic } \\
\text { functioning. }\end{array}$ & $\begin{array}{l}\text { No randomization or } \\
\text { control group, fairly } \\
\text { homogenous group. Need } \\
\text { for fidelity measures. One } \\
\text { could argue that those } \\
\text { students with study results }\end{array}$ & $\begin{array}{l}\text { School nurses found it difficult } \\
\text { to find uninterrupted time to } \\
\text { deliver intervention to students. }\end{array}$ \\
\hline
\end{tabular}




\begin{tabular}{|c|c|c|c|c|c|}
\hline $\begin{array}{l}\text { First } \\
\text { Author, } \\
\text { Year }\end{array}$ & Theory & $\begin{array}{l}\text { Country } \\
\text { Design } \\
\text { Sample }\end{array}$ & Intervention Summary & Risk of Bias & Implications \\
\hline & & $\begin{array}{l}9 \text { school } \\
\text { nurses, } 11 \\
\text { students age } 5- \\
11 \text { with } \\
\text { elevated } \\
\text { symptoms of } \\
\text { anxiety }\end{array}$ & & $\begin{array}{l}\text { indicating anxiety } \\
\text { diagnosis should have } \\
\text { been referred rather than } \\
\text { receiving potentially sub- } \\
\text { optimal care from a school } \\
\text { nurse. }\end{array}$ & \\
\hline $\begin{array}{l}\text { Olowokere, } \\
2014 \\
\text { Journal of } \\
\text { School } \\
\text { Nursing }\end{array}$ & Not reported & $\begin{array}{l}\text { Nigeria } \\
\text { quasi- } \\
\text { experimental } \\
\text { design (pretest- } \\
\text { posttest } \\
\text { nonequivalent } \\
\text { group design) } \\
15 \text { nurses, } 14 \\
\text { teachers from } 2 \\
\text { schools, } 109 \\
\text { children } \\
\text { determined } \\
\text { vulnerable for } \\
\text { psychosocial } \\
\text { issues (50 from } \\
\text { the randomized } \\
\text { school and } 59 \\
\text { from control } \\
\text { school) }\end{array}$ & $\begin{array}{l}\text { Nurses were trained, then nurses } \\
\text { trained teachers using same modules, } \\
\text { teachers and school nurses worked } \\
\text { together to identify vulnerable students } \\
\text { using an instrument. Student } \\
\text { experiment } 1 \text { group received resilience } \\
\text { training only, group } 2 \text { participated in } \\
\text { support groups where life skills were } \\
\text { taught, and group } 3 \text { received both. } \\
\text { Control group school nurses, teachers, } \\
\text { and students received no intervention. } \\
\text { Authors do not mentioned who } \\
\text { delivered resilience program, but } \\
\text { teachers facilitated support group. }\end{array}$ & $\begin{array}{l}\text { Authors report low } \\
\text { statistical power. Relatively } \\
\text { low sample size. } \\
\text { Recruitment process- } \\
\text { students with low scores in } \\
\text { only some content areas } \\
\text { participated. Future studies } \\
\text { should consider which } \\
\text { content areas were found } \\
\text { to be vulnerable for each } \\
\text { student and should better } \\
\text { track psychosocial } \\
\text { outcome measures. }\end{array}$ & $\begin{array}{l}\text { School nurses' training of } \\
\text { teachers can influence } \\
\text { interventions teachers provide } \\
\text { for students. }\end{array}$ \\
\hline $\begin{array}{l}\text { Ramirez, } \\
2013 \\
\text { BMC } \\
\text { Psychiatry }\end{array}$ & Not reported & $\begin{array}{l}\text { US } \\
\text { pilot quasi- } \\
\text { experimental } \\
20 \text { middle/high } \\
\text { school children }\end{array}$ & $\begin{array}{l}\text { Listen (reflective listening and non- } \\
\text { invasive questioning), protect (use K6 } \\
\text { screener to identify response to } \\
\text { trauma and refer those at risk for } \\
\text { maladaptive responses), connect (to } \\
\text { resources and advanced care as } \\
\text { needed) }\end{array}$ & $\begin{array}{l}\text { LPC is intended to be } \\
\text { offered soon after trauma, } \\
\text { but this intervention did not } \\
\text { occur until } 10 \text { months later, } \\
\text { which may skew } \\
\text { effectiveness. Small } \\
\text { sample size and } \\
\text { recruitment by self- or }\end{array}$ & $\begin{array}{l}\text { LPC is a feasible intervention } \\
\text { for school nurses and well } \\
\text { received by students who } \\
\text { experienced trauma. School } \\
\text { nurses can use this } \\
\text { intervention soon after a } \\
\text { traumatic event, including } \\
\text { natural disaster, school }\end{array}$ \\
\hline
\end{tabular}




\begin{tabular}{|c|c|c|c|c|c|}
\hline $\begin{array}{l}\text { First } \\
\text { Author, } \\
\text { Year }\end{array}$ & Theory & $\begin{array}{l}\text { Country } \\
\text { Design } \\
\text { Sample }\end{array}$ & Intervention Summary & Risk of Bias & Implications \\
\hline & & $\begin{array}{l}\text { from } 6 \text { different } \\
\text { schools }\end{array}$ & & $\begin{array}{l}\text { school nurse referral result } \\
\text { in limited generalizability. } \\
\text { This study was unable to } \\
\text { control for effectiveness for } \\
\text { different types of trauma. } \\
\text { Data on number of } \\
\text { students who actually } \\
\text { sought further mental } \\
\text { health care services was } \\
\text { not gathered, missing a } \\
\text { critical outcome of the LPC } \\
\text { program. }\end{array}$ & $\begin{array}{l}\text { shooting, loss of loved one, } \\
\text { etc. }\end{array}$ \\
\hline $\begin{array}{l}\text { Spratt, } \\
2010 \\
\text { Pastoral } \\
\text { Care in } \\
\text { Education }\end{array}$ & Not reported & $\begin{array}{l}\text { UK } \\
\text { Qualitative } \\
25 \text { school nurse } \\
\text { managers }\end{array}$ & $\begin{array}{l}\text { Theme of school nurses building } \\
\text { relationships with students and taking } \\
\text { a holistic approach were linked to } \\
\text { mental health care. However, lack of } \\
\text { resources (time/personnel), lack of } \\
\text { training/confidence, and tension } \\
\text { between offering proactive and } \\
\text { reactive care were barriers. }\end{array}$ & $\begin{array}{l}\text { No interviews with school } \\
\text { nurses or students to } \\
\text { balance the views } \\
\text { expressed by school nurse } \\
\text { managers. Focus on } \\
\text { Scottish schools and their } \\
\text { school health model may } \\
\text { not be generalizable to US } \\
\text { schools and school nursing } \\
\text { models. }\end{array}$ & $\begin{array}{l}\text { School nurses offer support in } \\
\text { ways that students find } \\
\text { accessible and helpful. They } \\
\text { can form relationships that } \\
\text { support resilience. }\end{array}$ \\
\hline $\begin{array}{l}\text { Stallard, } \\
2008 \\
\text { European } \\
\text { Child and } \\
\text { Adolescent } \\
\text { Psychiatry }\end{array}$ & $\begin{array}{l}\text { Cognitive } \\
\text { behavior } \\
\text { theory }\end{array}$ & $\begin{array}{l}\text { UK } \\
1 \text { year follow up } \\
\text { pre-test post- } \\
\text { test } \\
106 \text { 9-10-year } \\
\text { olds }\end{array}$ & Sessions of universal CBT in schools & $\begin{array}{l}\text { Lack of comparison group, } \\
\text { inability to know how many } \\
\text { students would have } \\
\text { become high risk if they } \\
\text { had NOT participated, and } \\
\text { attrition rate (was similar } \\
\text { with other studies of this } \\
\text { intervention). Some } \\
\text { improvements in anxiety } \\
\text { and self-esteem could be } \\
\text { due to natural } \\
\text { developmental changes of } \\
\text { students over the } 12 \\
\text { months. Positive changes }\end{array}$ & $\begin{array}{l}\text { While time consuming, a } \\
\text { universal CBT program is an } \\
\text { option. Those with PNES will } \\
\text { likely need more targeted } \\
\text { interventions, but this suggests } \\
\text { that school nurses are capable } \\
\text { of delivering CBT and students } \\
\text { are receptive and responsive. }\end{array}$ \\
\hline
\end{tabular}




\begin{tabular}{|c|c|c|c|c|c|}
\hline $\begin{array}{l}\text { First } \\
\text { Author, } \\
\text { Year }\end{array}$ & Theory & $\begin{array}{l}\text { Country } \\
\text { Design } \\
\text { Sample }\end{array}$ & Intervention Summary & Risk of Bias & Implications \\
\hline & & & & $\begin{array}{l}\text { were seen in } 67 \% \text { of } \\
\text { participants either at } 3 \text { or } \\
12 \text { months. }\end{array}$ & \\
\hline $\begin{array}{l}\text { Vessey, } \\
2011 \\
\text { Journal of } \\
\text { School } \\
\text { Nursing }\end{array}$ & Not reported & $\begin{array}{l}\text { US } \\
\text { Two-phased, } \\
\text { mixed method } \\
\text { design. } \\
11 \text { schools for } \\
\text { phase } 1,8 \\
\text { school for } \\
\text { phase } 2,65 \\
\text { students age } 8- \\
14\end{array}$ & $\begin{array}{l}\text { School nurse-led support groups in } \\
\text { strengthening student resilience using } \\
12 \text { webisodes, support group } \\
\text { discussion and activities }\end{array}$ & $\begin{array}{l}\text { School nurse's role was } \\
\text { not the only factor in } \\
\text { improved findings-role of } \\
\text { friendship important, } \\
\text { concern for those with } \\
\text { disability being singled out } \\
\text { to attend support group } \\
\text { meetings. RCT would be } \\
\text { more rigorous and } \\
\text { generalizable. Effects over } \\
\text { time should be evaluated. } \\
\text { No attempts were made to } \\
\text { measure effect of parents } \\
\text { and school employees } \\
\text { being trained on bullying } \\
\text { messages as well. }\end{array}$ & $\begin{array}{l}\text { School nurses can provide this } \\
\text { care themselves or in } \\
\text { conjunction with } \\
\text { interdisciplinary group. Visiting } \\
\text { school nurse is less } \\
\text { stigmatized than principal or } \\
\text { counselor. }\end{array}$ \\
\hline $\begin{array}{l}\text { Wall, } 2005 \\
\text { Journal of } \\
\text { Pediatric } \\
\text { Health } \\
\text { Care }\end{array}$ & $\begin{array}{l}\text { Developmental } \\
\text { theory, } \\
\text { mindfulness }\end{array}$ & $\begin{array}{l}\text { US } \\
\text { feasibility study } \\
\text { of education } \\
\text { program } \\
\text { Unknown } \\
\text { number of } \\
\text { middle school } \\
\text { boys and girls. }\end{array}$ & Tai Chi and mindfulness training & $\begin{array}{l}\text { Lack of details about } \\
\text { number of students } \\
\text { participating, } \\
\text { demographics of } \\
\text { participants. No } \\
\text { comparison group. }\end{array}$ & $\begin{array}{l}\text { Lacked enough data to draw } \\
\text { any conclusions other than } \\
\text { program appears to be feasible } \\
\text { in school. }\end{array}$ \\
\hline
\end{tabular}

$\mathrm{RCT}=$ randomized control trial; SEA=Southeast Asia; $\mathrm{CBSB}=$ cognitive behavioral skill building; CBT-cognitive behavioral therapy; COPE=Coping Openly and Personally with Epilepsy; LPC=Listen Protect Connect; PNES=psychogenic non-epileptic seizures 
Table 2

Intervention Characteristics and Categorized Outcomes

\begin{tabular}{|c|c|c|c|c|c|c|c|}
\hline & Intervention Characteristic & & & & & Outcome By Categor & \\
\hline $\begin{array}{l}\text { First } \\
\text { Author, } \\
\text { Year }\end{array}$ & Summary of Intervention & $\begin{array}{l}\text { Length of Overall } \\
\text { Intervention } \\
\text { Program/Sessions }\end{array}$ & Setting & $\begin{array}{l}\text { Type of } \\
\text { Audience (all, } \\
\text { at risk, } \\
\text { diagnosed) }\end{array}$ & $\begin{array}{l}\text { Type of } \\
\text { meeting } \\
\text { (individual, } \\
\text { group, class, } \\
\text { family) }\end{array}$ & $\begin{array}{l}\text { QOL } \\
\text { Academic } \\
\text { Mental Health (MH) }\end{array}$ & Findings \\
\hline $\begin{array}{l}\text { Bannink, } \\
2014\end{array}$ & $\begin{array}{l}\text { EHealth4U web-based } \\
\text { questionnaire and tailored } \\
\text { message with and without } \\
\text { school nurse consult. }\end{array}$ & $\begin{array}{l}\text { One-time } 45 \text { min. class } \\
\text { period to complete } \\
\text { online questionnaires, } \\
\text { read targeted messages, } \\
\text { read additional links, } \\
\text { and request school } \\
\text { nurse consultation if } \\
\text { desired. }\end{array}$ & $\begin{array}{l}\text { Classroom; } \\
\text { consultation } \\
\text { in school } \\
\text { nurse's office }\end{array}$ & $\begin{array}{l}\text { Targeted } \\
\text { messages: all } \\
\text { School nurse } \\
\text { consultation: } \\
\text { at-risk } \\
\text { students }\end{array}$ & Individual & $\begin{array}{l}\text { QOL: CHQ-CF-GH4 } \\
\text { Academic: ---- } \\
\text { MH: SDQ, YSR }\end{array}$ & $\begin{array}{l}\text { QOL: improved } \\
\text { B=2.79, 95\% Cl } \\
0.72-4.87 ; \\
d=0.09 \\
\text { MH: improved } \\
\text { SDQ: } \mathrm{B}=-1.79 \text {, } \\
95 \% \mathrm{Cl}-3.35 \text { to } \\
-0.22 ; \mathrm{d}=0.33 \text {; } \\
\text { YSR: } \mathrm{B}=-9.11 \text {, } \\
95 \% \mathrm{Cl}-17.52 \\
\text { to }-0.71 ; \\
d=0.34\end{array}$ \\
\hline $\begin{array}{l}\text { Clausson, } \\
2008\end{array}$ & $\begin{array}{l}\text { Therapeutic conver- } \\
\text { sations with families }\end{array}$ & $\begin{array}{l}3 \text { sessions per family, } \\
\text { approximately } 2-3 \\
\text { weeks apart; sessions } \\
\text { lasted } 1-1.5 \text { hrs each }\end{array}$ & $\begin{array}{l}\text { Families' } \\
\text { homes }\end{array}$ & $\begin{array}{l}\text { Families of } \\
\text { targeted } \\
\text { students with } \\
\text { habitual } \\
\text { subjective } \\
\text { health } \\
\text { complaints }\end{array}$ & Family & $\begin{array}{l}\text { QOL: -------- } \\
\text { Academic: ------- } \\
\text { MH: SDQ }\end{array}$ & $\begin{array}{l}\text { MH: improved; } \\
\text { no summary } \\
\text { statistics } \\
\text { provided }\end{array}$ \\
\hline $\begin{array}{l}\text { Fox, } \\
2005\end{array}$ & $\begin{array}{l}\text { School-based cognitive } \\
\text { behavioral mental health } \\
\text { intervention and } \\
\text { homework to decrease } \\
\text { depression in children }\end{array}$ & $\begin{array}{l}\text { After school for } 8 \\
\text { weeks, } 1 \mathrm{hr} \text { per weekly } \\
\text { session }\end{array}$ & $\begin{array}{l}\text { In-school } \\
\text { afterhours }\end{array}$ & $\begin{array}{l}\text { All (whose } \\
\text { parents gave } \\
\text { permission to } \\
\text { attend after- } \\
\text { school } \\
\text { intervention) }\end{array}$ & $\begin{array}{l}\text { Groups } \\
\text { divided by age }\end{array}$ & $\begin{array}{l}\text { QOL: -------- } \\
\text { Academic: ------- } \\
\text { MH: CDI }\end{array}$ & $\begin{array}{l}\text { MH: improved } \\
\text { t-value of } 4.89 \\
\text { (.000,2-tailed } \\
\text { significance) }\end{array}$ \\
\hline
\end{tabular}




\begin{tabular}{|c|c|c|c|c|c|c|c|}
\hline \multirow[b]{2}{*}{$\begin{array}{l}\text { First } \\
\text { Author, } \\
\text { Year }\end{array}$} & \multicolumn{5}{|c|}{ Intervention Characteristics } & \multicolumn{2}{|c|}{ Outcome By Category } \\
\hline & Summary of Intervention & $\begin{array}{l}\text { Length of Overall } \\
\text { Intervention } \\
\text { Program/Sessions }\end{array}$ & Setting & $\begin{array}{l}\text { Type of } \\
\text { Audience (all, } \\
\text { at risk, } \\
\text { diagnosed) }\end{array}$ & $\begin{array}{l}\text { Type of } \\
\text { meeting } \\
\text { (individual, } \\
\text { group, class, } \\
\text { family) }\end{array}$ & $\begin{array}{l}\text { QOL } \\
\text { Academic } \\
\text { Mental Health (MH) }\end{array}$ & Findings \\
\hline & $\begin{array}{l}\text { refugees from Southeast } \\
\text { Asia }\end{array}$ & & & & & & \\
\hline $\begin{array}{l}\text { Houck, } \\
2002\end{array}$ & $\begin{array}{l}\text { School-based support } \\
\text { groups with skill-building } \\
\text { or cognitive behavioral } \\
\text { focus }\end{array}$ & $\begin{array}{l}\text { Weekly } 45 \text {-minute } \\
\text { sessions for } 14 \text { weeks }\end{array}$ & $\begin{array}{l}\text { Within } \\
\text { school but } \\
\text { out of class }\end{array}$ & $\begin{array}{l}\text { Female } \\
\text { students at } \\
\text { risk for } \\
\text { depression } \\
\text { and suicide } \\
\text { risk }\end{array}$ & $\begin{array}{l}\text { Small support } \\
\text { group }\end{array}$ & $\begin{array}{l}\text { QOL: -------- } \\
\text { Academic: HSQ } \\
\text { (drop out) } \\
\text { MH: HSQ (stress, re- } \\
\text { source) }\end{array}$ & $\begin{array}{l}\text { Academic: } \\
\text { improved to no } \\
\text { risk } \mathrm{t}=1.53, \\
\mathrm{p} \leq .10 \\
\text { MH: improved } \\
\text { perceived } \\
\text { stress } \mathrm{t}=1.54 ; \\
\text { family distress } \\
\mathrm{t}=1.73, \mathrm{p} \leq .10\end{array}$ \\
\hline $\begin{array}{l}\text { Hoying, } \\
2016\end{array}$ & $\begin{array}{l}\text { School-based classroom } \\
\text { course for mental health } \\
\text { and physical activity }\end{array}$ & $\begin{array}{l}\text { Weekly 50-minute } \\
\text { sessions ( } 30 \text { min. } \\
\text { didactic, } 20 \text { min. } \\
\text { physical activity) for } 15 \\
\text { weeks }\end{array}$ & $\begin{array}{l}\text { Classroom } \\
\text { with referral } \\
\text { to school } \\
\text { nurse's office } \\
\text { and letter } \\
\text { sent home }\end{array}$ & All students & Class & $\begin{array}{l}\text { QOL: -------- } \\
\text { Academic: Self- } \\
\text { report academic } \\
\text { gains } \\
\text { MH: BYI-II }\end{array}$ & $\begin{array}{l}\text { Academic: } \\
\text { improved, no } \\
\text { significance } \\
\text { testing } \\
\text { MH: improved } \\
\text { anxiety, } \\
\text { medium effect } \\
\text { t=3.230, } \\
p=.003, \\
\text { Cohen's } \\
d=0.42, p<.10 ; \\
\text { for at-risk } \\
\text { students } \\
\text { improved self- } \\
\text { concept, }\end{array}$ \\
\hline
\end{tabular}




\begin{tabular}{|c|c|c|c|c|c|c|c|}
\hline \multirow[b]{2}{*}{$\begin{array}{l}\text { First } \\
\text { Author, } \\
\text { Year }\end{array}$} & \multicolumn{5}{|c|}{ Intervention Characteristics } & \multicolumn{2}{|c|}{ Outcome By Category } \\
\hline & Summary of Intervention & $\begin{array}{l}\text { Length of Overall } \\
\text { Intervention } \\
\text { Program/Sessions }\end{array}$ & Setting & $\begin{array}{l}\text { Type of } \\
\text { Audience (all, } \\
\text { at risk, } \\
\text { diagnosed) }\end{array}$ & $\begin{array}{l}\text { Type of } \\
\text { meeting } \\
\text { (individual, } \\
\text { group, class, } \\
\text { family) } \\
\end{array}$ & $\begin{array}{l}\text { QOL } \\
\text { Academic } \\
\text { Mental Health (MH) }\end{array}$ & Findings \\
\hline & & & & & & & $\begin{array}{l}\text { anxiety, } \\
\text { depression, } \\
\text { suicidal } \\
\text { ideation with } \\
\text { med-lg effect } \\
\text { size, } p<.10\end{array}$ \\
\hline $\begin{array}{l}\text { Kim, } \\
2015\end{array}$ & $\begin{array}{l}\text { Pilot study for school } \\
\text { nurses using engagement } \\
\text { practices to improve } \\
\text { students' readiness for } \\
\text { mental health services }\end{array}$ & $\begin{array}{l}\text { For low caseload school } \\
\text { nurses, } 21-30 \text { minutes. } \\
\text { For higher caseload, 5- } \\
10 \text { minutes. }\end{array}$ & $\begin{array}{l}\text { School health } \\
\text { office }\end{array}$ & $\begin{array}{l}\text { At risk (those } \\
\text { visiting health } \\
\text { office with s/s } \\
\text { possibly } \\
\text { related to } \\
\text { mental health } \\
\text { concern) }\end{array}$ & Individual & $\begin{array}{l}\text { QOL: -------- } \\
\text { Academic: ------- } \\
\text { MH: Youth } \\
\text { Readiness for } \\
\text { Services }\end{array}$ & $\begin{array}{l}\text { MH: improved } \\
\text { hope about }(t=- \\
0.48, d f=21, \\
p=.64) \text { and } \\
\text { perceived need } \\
\text { for mental } \\
\text { health services } \\
(t=-1.40, d f=21 \text {, } \\
p=.175)\end{array}$ \\
\hline $\begin{array}{l}\text { Lamb, } \\
1998\end{array}$ & $\begin{array}{l}\text { Nurse-led (PhD mental } \\
\text { health nurse) coping skills } \\
\text { group/ } \\
\text { homework for rural high } \\
\text { school students }\end{array}$ & $\begin{array}{l}8 \text { weeks (first half of } \\
\text { each session didactic, } \\
\text { second half experiential) }\end{array}$ & $\begin{array}{l}\text { Did not } \\
\text { specify } \\
\text { where inter- } \\
\text { vention took } \\
\text { place. } \\
\text { Assumed to } \\
\text { be during } \\
\text { school hours. }\end{array}$ & $\begin{array}{l}\text { At risk } \\
\text { according to } \\
\text { screening tool }\end{array}$ & $\begin{array}{l}\text { Group (10-12 } \\
\text { members } \\
\text { grouped } \\
\text { according to } \\
\text { grade level, } \\
\text { no mention of } \\
\text { gender) }\end{array}$ & $\begin{array}{l}\text { QOL: -------- } \\
\text { Academic: ------- } \\
\text { MH: JCS, RADS, LEC }\end{array}$ & $\begin{array}{l}\text { MH: more } \\
\text { improved } \\
\text { depressive } \\
\text { symptoms than } \\
\text { control } \\
\mathrm{p}=0.074, \text { more } \\
\text { supportive } \\
\text { coping use }\end{array}$ \\
\hline $\begin{array}{l}\text { Muggeo, } \\
2017\end{array}$ & $\begin{array}{l}\text { A brief school nurse-led } \\
\text { cognitive behavior-based } \\
\text { intervention to decrease } \\
\text { student anxiety }\end{array}$ & $\begin{array}{l}8 \text { weeks, sessions } 15-30 \\
\text { each }\end{array}$ & $\begin{array}{l}\text { Reserved } \\
\text { room } \\
\text { separate } \\
\text { from health }\end{array}$ & At risk & Individual & $\begin{array}{l}\text { QOL: -------- } \\
\text { Academic: BASC-2, } \\
\text { WJ-III, TOCA-C, } \\
\text { school attendance }\end{array}$ & $\begin{array}{l}\text { Academic: } \\
\text { significantly } \\
\text { lower teacher- } \\
\text { reported } \\
\text { concentration }\end{array}$ \\
\hline
\end{tabular}




\begin{tabular}{|c|c|c|c|c|c|c|c|}
\hline \multirow[b]{2}{*}{$\begin{array}{l}\text { First } \\
\text { Author, } \\
\text { Year }\end{array}$} & \multicolumn{5}{|c|}{ Intervention Characteristics } & \multicolumn{2}{|c|}{ Outcome By Category } \\
\hline & Summary of Intervention & $\begin{array}{l}\text { Length of Overall } \\
\text { Intervention } \\
\text { Program/Sessions }\end{array}$ & Setting & $\begin{array}{l}\text { Type of } \\
\text { Audience (all, } \\
\text { at risk, } \\
\text { diagnosed) }\end{array}$ & $\begin{array}{l}\text { Type of } \\
\text { meeting } \\
\text { (individual, } \\
\text { group, class, } \\
\text { family) }\end{array}$ & $\begin{array}{l}\text { QOL } \\
\text { Academic } \\
\text { Mental Health }(\mathrm{MH})\end{array}$ & Findings \\
\hline & & & $\begin{array}{l}\text { office when } \\
\text { possible }\end{array}$ & & & $\begin{array}{l}\text { MH: SCARED, ADIS- } \\
\text { IV P/C, CGI-S, CGI-I, } \\
\text { CSI-24, CGAS, }\end{array}$ & $\begin{array}{l}\text { problems t(10) } \\
=2.33, \mathrm{p}=.02, \\
95 \% \mathrm{Cl}[.01, \\
.73], \text { Cohen's d } \\
=.35 ; 2 \text { week } \\
\text { absences } \\
\text { reduced from } \\
16 \text { to } 4 \\
\text { MH: Improved } \\
\text { anxiety t(9) = } \\
3.36, \mathrm{p}=.004, \\
95 \% \mathrm{Cl}[3.24, \\
16.56], \text { Cohen's } \\
\mathrm{d}=0.81 ; \\
\text { improved } \\
\text { somatic } \\
\text { symptoms t(9) } \\
=2.21, \mathrm{p}= \\
.027,95 \% \mathrm{Cl}[- \\
.18,15.98], \\
\text { Cohen's d = } \\
.85 ; \\
\text { significantly } \\
\text { higher } \\
\text { functioning } \\
\mathrm{t}(10)=-3.45, \mathrm{p} \\
=.003,95 \% \mathrm{Cl} \\
\end{array}$ \\
\hline
\end{tabular}




\begin{tabular}{|c|c|c|c|c|c|c|c|}
\hline \multirow[b]{2}{*}{$\begin{array}{l}\text { First } \\
\text { Author, } \\
\text { Year }\end{array}$} & \multicolumn{5}{|c|}{ Intervention Characteristics } & \multicolumn{2}{|l|}{ Outcome By Category } \\
\hline & Summary of Intervention & $\begin{array}{l}\text { Length of Overall } \\
\text { Intervention } \\
\text { Program/Sessions }\end{array}$ & Setting & $\begin{array}{l}\text { Type of } \\
\text { Audience (all, } \\
\text { at risk, } \\
\text { diagnosed) }\end{array}$ & $\begin{array}{l}\text { Type of } \\
\text { meeting } \\
\text { (individual, } \\
\text { group, class, } \\
\text { family) }\end{array}$ & $\begin{array}{l}\text { QOL } \\
\text { Academic } \\
\text { Mental Health }(\mathrm{MH})\end{array}$ & Findings \\
\hline & & & & & & & $\begin{array}{l}{[-12.11,-2.61]} \\
\text { Cohen's d =.35 }\end{array}$ \\
\hline $\begin{array}{l}\text { Olo- } \\
\text { wokere, } \\
2014\end{array}$ & $\begin{array}{l}\text { Resilience training support } \\
\text { group meetings. Unclear if } \\
\text { teacher, school nurse, or } \\
\text { other researcher } \\
\text { performed the inter- } \\
\text { vention. }\end{array}$ & $\begin{array}{l}6 \text { weeks, } 2 \text { hrs per } \\
\text { session for students in } \\
\text { resilience-only or } \\
\text { support group-only } \\
\text { intervention groups. } 6 \\
\text { weeks, } 4 \text { hrs per week } \\
\text { for resilience training } \\
\text { and support group } \\
\text { intervention group. }\end{array}$ & $\begin{array}{l}\text { School but } \\
\text { unsure of } \\
\text { location } \\
\text { within school }\end{array}$ & $\begin{array}{l}\text { At risk as } \\
\text { identified by } \\
\text { trained } \\
\text { teachers and } \\
\text { school nurses }\end{array}$ & Group & $\begin{array}{l}\text { QOL: --------- } \\
\text { Academic: -------- } \\
\text { MH: The Resilience } \\
\text { Centre Resilience } \\
\text { Scale, Spence's } \\
\text { children anxiety } \\
\text { scale, CES-D for } \\
\text { children, Rosenberg } \\
\text { self-esteem scale, } \\
\text { Social } \\
\text { Connectedness } \\
\text { scale }\end{array}$ & $\begin{array}{l}\text { MH: improved } \\
\text { resilience } M= \\
19.15, t=4.37, \\
p=.000 ; \\
\text { significant } \\
\text { improvement } \\
\text { in depression } \\
M 11 \%=4.94, \\
t=2.26, p=.03 ; \\
\text { self-esteem } \\
M=3.27, \\
t=2.26, p=.03, \\
\text { and social } \\
\text { connectedness } \\
M=2.86, \\
t=3.16, p=.002\end{array}$ \\
\hline $\begin{array}{l}\text { Ramirez, } \\
2013\end{array}$ & $\begin{array}{l}\text { Listen Protect Connect } \\
\text { (LPC), a school-based } \\
\text { program of Psychological } \\
\text { First Aid delivered by non- } \\
\text { mental health professional }\end{array}$ & $\begin{array}{l}\text { One session, avg } 25 \mathrm{~min} \\
\text { (range } 10-40 \mathrm{~min} \text { ) }\end{array}$ & $\begin{array}{l}\text { School nurse } \\
\text { office }\end{array}$ & $\begin{array}{l}\text { At risk, based } \\
\text { upon health } \\
\text { office visits } r / t \\
\text { non-specific } \\
\text { physical } \\
\text { symptoms, } \\
\text { student report } \\
\text { of trauma/ }\end{array}$ & Individual & $\begin{array}{l}\text { QOL: --------- } \\
\text { Academic: -------- } \\
\text { MH: Modified Child } \\
\text { PTSD Symptom } \\
\text { Scale, CES-D, } \\
\text { MSPSS, Healthy Kids } \\
\text { Resilience Measure }\end{array}$ & $\begin{array}{l}\text { MH: improved } \\
\text { depression } \\
\text { scores, PTSD } \\
\text { symptoms, } \\
\text { social support, } \\
\text { school } \\
\text { connection } p< \\
0.01\end{array}$ \\
\hline
\end{tabular}




\begin{tabular}{|c|c|c|c|c|c|c|c|}
\hline \multirow[b]{2}{*}{$\begin{array}{l}\text { First } \\
\text { Author, } \\
\text { Year }\end{array}$} & \multicolumn{5}{|c|}{ Intervention Characteristics } & \multicolumn{2}{|c|}{ Outcome By Category } \\
\hline & Summary of Intervention & $\begin{array}{l}\text { Length of Overall } \\
\text { Intervention } \\
\text { Program/Sessions }\end{array}$ & Setting & $\begin{array}{l}\text { Type of } \\
\text { Audience (all, } \\
\text { at risk, } \\
\text { diagnosed) }\end{array}$ & $\begin{array}{l}\text { Type of } \\
\text { meeting } \\
\text { (individual, } \\
\text { group, class, } \\
\text { family) }\end{array}$ & $\begin{array}{l}\text { QOL } \\
\text { Academic } \\
\text { Mental Health }(\mathrm{MH})\end{array}$ & Findings \\
\hline & & & & $\begin{array}{l}\text { distress, or } \\
\text { unexcused } \\
\text { absences }\end{array}$ & & $\begin{array}{l}\text { of School } \\
\text { Connectedness }\end{array}$ & \\
\hline $\begin{array}{l}\text { Stallard, } \\
2008\end{array}$ & $\begin{array}{l}\text { A universal cognitive } \\
\text { behavior therapy } \\
\text { emotional health program }\end{array}$ & $\begin{array}{l}10 \text { weekly one-hour } \\
\text { sessions }\end{array}$ & Class & All & $\begin{array}{l}\text { Whole classes } \\
\text { with small } \\
\text { group } \\
\text { activities }\end{array}$ & $\begin{array}{l}\text { QOL: -------- } \\
\text { Academic: } \\
\text { Academic self- } \\
\text { esteem } \\
\text { MH: Spence } \\
\text { children's anxiety } \\
\text { scale, generalized } \\
\text { anxiety disorder, } \\
\text { Culture free self- } \\
\text { esteem } \\
\text { questionnaire form } \\
\text { B }\end{array}$ & $\begin{array}{l}\text { Academic: } \\
\text { significant } \\
\text { improvement } \\
\text { of self-esteem } \\
F(3,323)=6.55 \text {, } \\
P=.0001 \\
\text { MH: significant } \\
\text { improvement } \\
\text { in and anxiety } \\
F(3,323)=8.58 \text {, } \\
P=.0001\end{array}$ \\
\hline $\begin{array}{l}\text { Vessey, } \\
2011\end{array}$ & $\begin{array}{l}\text { School nurse-led support } \\
\text { group for students with } \\
\text { disabilities to provide } \\
\text { resiliency skills. Used Take } \\
\text { a Stand, Lend a Hand, Stop } \\
\text { Bullying Now }\end{array}$ & $\begin{array}{l}\text { Approximately every } 2 \\
\text { weeks for } 24 \text { weeks ( } 12 \\
\text { sessions } 30 \text { min per } \\
\text { session) }\end{array}$ & $\begin{array}{l}\text { School, but } \\
\text { unsure of } \\
\text { location } \\
\text { within school } \\
\text { or if during } \\
\text { or outside of } \\
\text { school hours }\end{array}$ & $\begin{array}{l}\text { At risk (due to } \\
\text { having a } \\
\text { disability) }\end{array}$ & Group & $\begin{array}{l}\text { QOL: -------- } \\
\text { Academic: -------- } \\
\text { MH: CATS, PSC, } \\
\text { PHCSCS }\end{array}$ & $\begin{array}{l}\text { MH: improved } \\
\text { perception of } \\
\text { peer } \\
\text { interactions } \\
t=3.432 \\
p=.001 \text { and self } \\
t=2.546 \\
p=.007\end{array}$ \\
\hline $\begin{array}{l}\text { Wall, } \\
2005\end{array}$ & $\begin{array}{l}\text { Tai chi and mindfulness- } \\
\text { based stress reduction } \\
\text { educational program }\end{array}$ & $\begin{array}{l}5 \text { weekly one-hour } \\
\text { sessions }\end{array}$ & $\begin{array}{l}\text { School } \\
\text { (unsure of } \\
\text { location in }\end{array}$ & $\begin{array}{l}\text { All (who } \\
\text { received } \\
\text { permission) }\end{array}$ & Group & $\begin{array}{l}\text { QOL: --------- } \\
\text { Academic: -------- }\end{array}$ & $\begin{array}{l}\text { MH: improved } \\
\text { sense of } \\
\text { calm/peace, }\end{array}$ \\
\hline
\end{tabular}




\begin{tabular}{|c|c|c|c|c|c|c|c|}
\hline \multirow[b]{2}{*}{$\begin{array}{l}\text { First } \\
\text { Author, } \\
\text { Year }\end{array}$} & \multicolumn{5}{|c|}{ Intervention Characteristics } & \multicolumn{2}{|c|}{ Outcome By Category } \\
\hline & Summary of Intervention & $\begin{array}{l}\text { Length of Overall } \\
\text { Intervention } \\
\text { Program/Sessions }\end{array}$ & Setting & $\begin{array}{l}\text { Type of } \\
\text { Audience (all, } \\
\text { at risk, } \\
\text { diagnosed) }\end{array}$ & $\begin{array}{l}\text { Type of } \\
\text { meeting } \\
\text { (individual, } \\
\text { group, class, } \\
\text { family) }\end{array}$ & $\begin{array}{l}\text { QOL } \\
\text { Academic } \\
\text { Mental Health (MH) }\end{array}$ & Findings \\
\hline & & & $\begin{array}{l}\text { school and if } \\
\text { during or } \\
\text { outside } \\
\text { school hours) }\end{array}$ & & & $\begin{array}{l}\text { MH: Verbal self- } \\
\text { report on calmness, } \\
\text { relaxation, } \\
\text { improved sleep, less } \\
\text { reactivity, self- } \\
\text { awareness }\end{array}$ & $\begin{array}{l}\text { sleep, patience } \\
\text { (no statistical } \\
\text { data) }\end{array}$ \\
\hline
\end{tabular}

$\mathrm{SDQ}=$ Strengths and Difficulties Questionnaire; YSR= Youth Self Report; CHQ-CF-GH4=Child Health Questionnaire-Child Form; HSQ=High School Questionnaire; BYI-II=Beck Youth Inventory Second Edition; JCS=Jalowiec Coping Scale; RADS=Reynolds Adolescent Depression Scale; LEC=Life Events Checklist; SCARED=Screen for Child Anxiety-Related Emotional Disorders, Child and Parent Versions; ADIS-IV P/C=Anxiety Disorders Interview Schedule for DSM-IV, Parent and Child Versions; CGI-S=Clinical Global Impression-Severity Scale; CGI-I=Clinical Global Impression Improvement Scale; CSI-24=Children's Somatization Inventory; CGAS=The Children's Global Assessment Scale; TOCA-C=Teacher Observation of Classroom Adaptation-Checklist; BASC-2=Behavior Assessment System for Children; WJ-III=Woodcock-Johnson Tests-Achievement and Cognitive Batteries; $C D I=C h i l d r e n ' s$ Depression Inventory; CES-D= Center for Epidemiologic Studies Depression Scale; MSPSS= Multidimensional Scale of Perceived Support; CATS= Child-Adolescent Teasing Scale; PSC= Pediatric Symptom Checklist; PHCSCS= Piers-Harris Children's Selfconcept Scale 